\title{
THE INFLUENCE OF INFORMATION TECHNOLOGIES ON CORPORATE GOVERNANCE IN COMPANIES
}

\author{
Dalibor Radovanović \\ Tijana Radojević1, \\ Danica Rajin ${ }^{2}$
}

${ }^{1}$ Singidunum University, Belgrade, Serbia

${ }^{2} \mathrm{FEFA}$,

Belgrade, Serbia
Correspondence:

Dalibor Radovanović

e-mail:

dradovanovic@singidunum.ac.rs

\begin{abstract}
:
The aim of this paper is to examine the influence and contribution of information technologies on corporate governance in companies in Serbia. Corporate governance in IT management is a subgroup of corporate governance disciplines that focus on IT systems, their performance, as well as risk management. On the one hand, the increased interest in information and technology governance is related to the compliance initiatives, such as Sarbanes-Oxley in the United States and Basel II in Europe. On the other hand, even more importantly, the interest stems from the demand for a higher degree of accountability in decision-making processes - the processes that are related to the usage of information technology in the best interest of all stakeholders.
\end{abstract}

Keywords:

corporate governance, information technology, IT governance.

\section{INTRODUCTION}

There is a common belief within the scope of information and technology governance that IT capacity is connected with the choices concerning investment, with long-term effects on participants of different profiles, made by the top management.

Corporate governance of information technology represents a system where all participants, i.e. not only the board of directors and executive board, but also customers and staff, have responsibilities in the decision-making processes that affect IT. ${ }^{1}$

This prevents both IT and business leaders from making IT related decisions, without having any responsibilities for their decisions and actions and without any impact they commonly have on strategic goals achievement.

IT governance determines the level of integration and control that an organization has over its IT investments. Information technology is a widespread phenomenon in business environment today. The essential value of information technology must be fully integrated into every aspect of business operations, not only used as an individual IT function. The level of IT integration has a significant effect on the way in which an organization defines its mission, achieves its strategic goals and communicates the vision of its development. The IT management audit includes the highest levels of organizational management and crosses the boundaries among different departments.

\section{THE IMPORTANCE OF IT PROJECTS PERFORMANCE MEASUREMENT}

Performance measurement forms the foundation for a firm and proper information and technology governance. In order for an organization to possess a good management, the spot at which the true value of its IT projects lies must be determined. A distinct

1 Cater-Steel, A. (2008). Information Technology Governance and Service Management: Frameworks and Adaptations, IGI Global. 2008. 
set of performance measures enables the management to quantify success and define the areas to focus on, so that both the effectiveness and efficiency of IT projects could be achieved. Without performance measures, it would be rather difficult to measure the progress that IT projects have made while achieving IT goals. Performance measures benefits include, but are not limited to: ${ }^{2}$

- IT services quality improvement;

- IT risk reduction;

- Improved IT services realization;

- Cost reduction in IT services realization.

There exist two types of performance measures: ${ }^{3}$

- development measures, used to quantify the performance of IT developing projects,

- measures of services, used to quantify the success of permanent or repetitive IT services.

For the purposes of performances measurement development, a set of measures were prescribed in order to monitor the project's development, which provides the organization with an insight into the project progress at all the stages.

Generally, IT services are allocated to a program according to the program's IT services measurement.

It would not be possible to list all the different measures used for the effective IT measurement, but the measures that follow are common in most organizations, and can be used for both project development and services - depending on the place where the data have been collected and the manner in which this was done: ${ }^{4}$

- IT - related costs by category and by activity.

- Number of IT - related staff members and costs analyzed by activities.

- Outsourcing levels/proportions.

- Operational risk incidents related to IT (number and value). - The organization can determine the way in which the risk is approached - by identifying risks, ways in which they can be reduced, as well as the failure price, in case the risks have not been reduced; the results of these measurements should be delivered to the top management.

Other examples of common measures include the comparison of - IT staff with full time employees and associates, workstation costs, operational risk incidents related to IT (number and value), IT security incidents (number and value), various IT project measurements, and IT investment management level.

2 Haes, S. D. and Grembergen, W. V. (2009). An Exploratory Study into IT Governance Implementations and its Impact on Business/ IT Alignment, Information Systems Management, Vol. 26, 2009, pp.123-137.

3 Weill, P., and Ross, J. W. (2004). IT governance - How top performers manage IT decision rights for superior results, Harvard Business School Press, 2004.

\section{METHODOLOGY}

The aim of the research was to examine the influence and contribution of information technologies to the operations of companies in Serbia. In order to achieve the broadest possible representation of the sample, the survey includes companies of different types, ownership structure, size, as well as numerous areas of business.

The basic method of data collection was an anonymous survey consisting of 40 multiple-choice questions. In order to understand the received answers better and to collect additional information, required for the analysis, interviews were also conducted with almost a third of the overall number of respondents. The survey was created using the Lime survey application aimed at being simple and user-friendly. Questionnaire links were sent to the respondents by e-mail or private messages via LinkedIn professional social network. In order to determine the attitude of various groups towards the level of development, significance and contribution of information technology to the companies in Serbia, the respondents were divided into two groups. In addition, given their nature, some of the questions were posed only to the respondents from the IT, i.e. auditing area of endeavor: ${ }^{5}$

- The first group of respondents consisted of: IT supervisors or persons responsible for information technology management, internal audit executives, IT auditors and auditors.

- The second group of respondents consisted of: executive directors and middle managers who use IT services in the companies that were in the analyzed sample.

\section{RESULTS AND DISCUSSION}

The results of the research show that the contribution of IT to corporate governance is widely recognized. According to the respondents, this contribution is mostly reflected in creating an additional value for the company through IT investments. On the other hand, enabling rapid business changes by IT is the smallest dimension presented in the Figure 1. Respondents state that the inability to facilitate rapid business changes is largely caused by poor or outdated IT infrastructure, lack of budget for IT investments, long-term procurement procedures (selecting and agreeing upon contracts with IT consultants), inaccurate user requirements and insufficient understanding of business needs.

4 ITIL, (2007). An Introductory Overview of ITIL V3. London: The UK Chapter of the it SMF, 2007.

5 Radovanović, D. (2016). Uticaj kontrole i revizije informacionih sistema na uspešnost i efikasnost upravljanja i poslovanja kompanija u Srbiji, Univerzitet Singidunum, 171. 
Figure 1. IT contribution to corporate governance

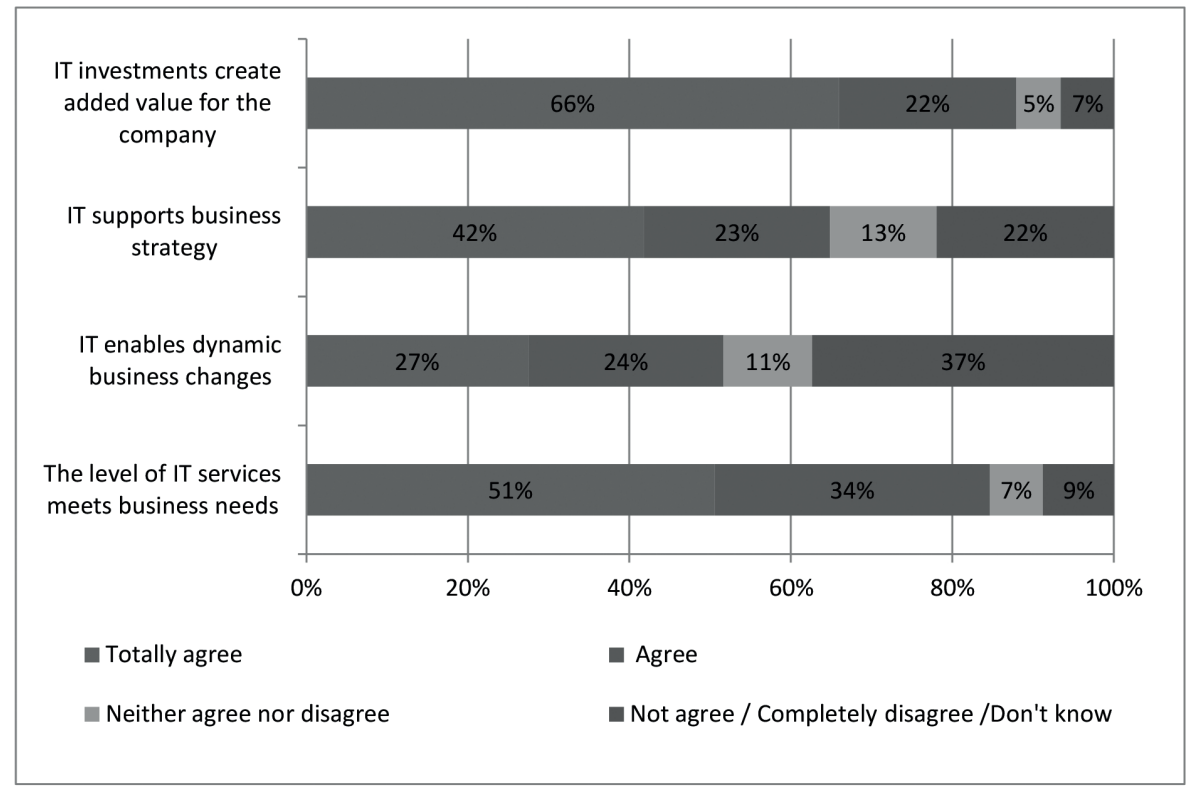

Table 1 shows that the answers provided by IT respondents are, generally, more positive than those provided by business respondents. The biggest difference is visible as regards the claim that IT supports the business strategy, where almost $80 \%$ of IT respondents fully agree or agree with the claim, while $62.79 \%$ of business respondents, i.e. $16.78 \%$ less, have the same opinion.

Table 1. A comparative overview of the percentages of IT and business respondents who chose either "Completely agree" or "agree" for each of the claims about the IT contribution to the business operations

\begin{tabular}{lcc}
\hline IT contribution to business & IT respondents & $\begin{array}{c}\text { Business } \\
\text { respondents }\end{array}$ \\
\hline IT investments create an additional value for the company & $93,75 \%$ & $81,40 \%$ \\
\hline IT supports business strategy & $79,17 \%$ & $62,79 \%$ \\
\hline IT enables dynamic business changes & $58,33 \%$ & $44,19 \%$ \\
\hline The level of IT services meets business needs & $89,58 \%$ & $79,07 \%$ \\
\hline
\end{tabular}

Source: Authors' calculation

Furthermore, the analysis of the survey results showed that business respondents who consider IT to be a support to the business strategy come from large and medium-sized enterprises with majority foreign ownership (over 80 cases). According to the respondents, the reason for such a situation is owing to the fact that the mentioned companies, due to the volume of business transactions and the higher level of maturity of IT corporate management, have a greater awareness regarding the importance and necessity of IT development - and thus invest more money in IT resources. Additionally, as regards the claim that IT supports business needs, a more positive attitude is noticed among business respondents in companies that outsource IT services than in those with an internal IT department or an employee performing IT related operations.
The results of the survey show that around $87 \%$ of respondents recognize that the company has benefited from IT investments. The majority of respondents also regard the cost reduction as a major benefit (through increased efficiency and/or productivity). This benefit is, as well as the benefit of enhanced customer service, especially recognized among large and medium-sized companies (specifically retail, IT/ telecommunications), while smaller companies, consider the increased security of information to be the most important benefit. The illustrated response structure complies with the number of business transactions that the companies perform. ${ }^{6}$

6 Radovanović, D. (2016). Uticaj kontrole i revizije informacionih sistema na uspešnost i efikasnost upravljanja i poslovanja kompanija u Srbiji, Univerzitet Singidunum, 171. 


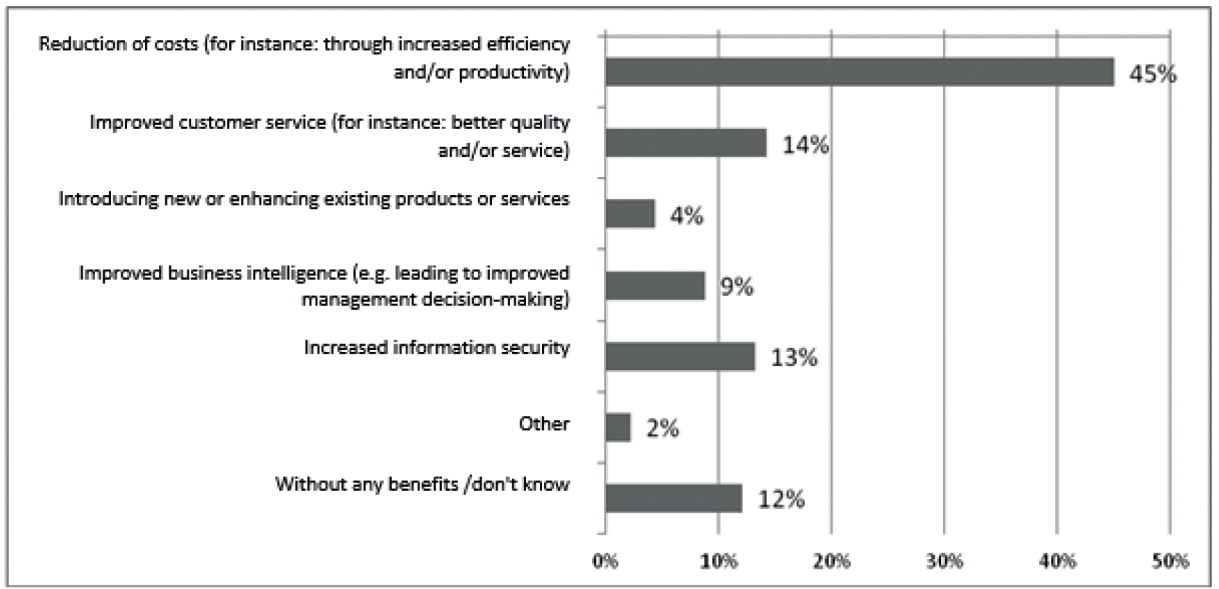

Most respondents (67\%) believe that the difficulties in applications implementation, as well as organizational culture are the most common barriers that have prevented the full benefits from IT investments to be derived.

Figure 3. Realizing the full benefits of IT investments

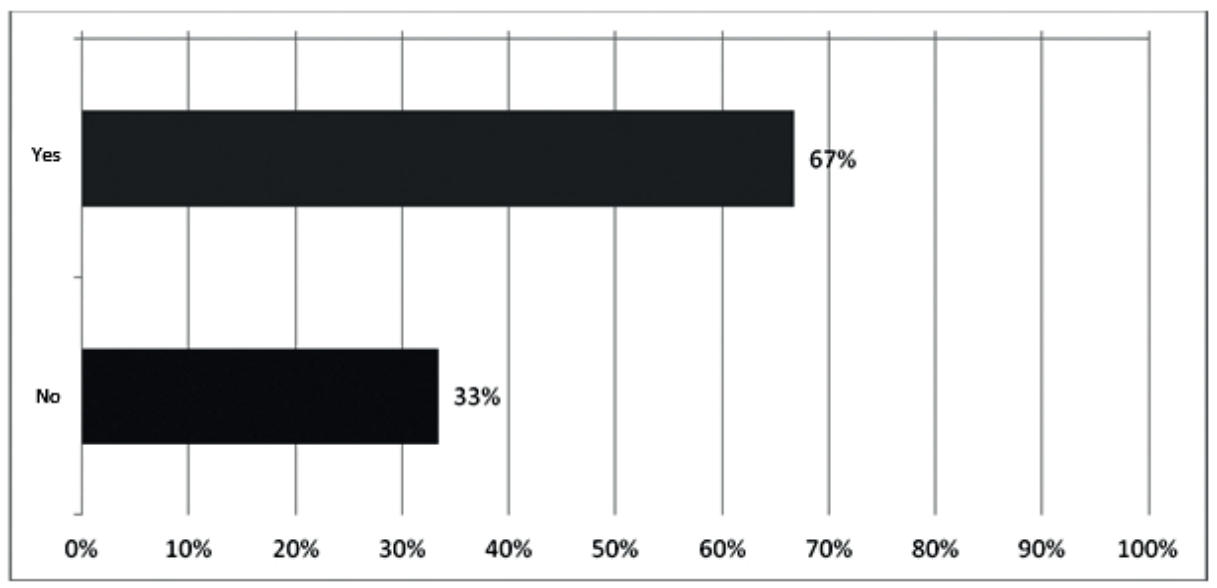

Sixty five percent of respondents indicated that IT director is a member of the senior management team in their companies (Figure 4). This position within the senior management team is more likely to happen in companies with 200 or more employees (85\%) than in those with less than 200 employees (15\%).

These results confirm the great importance of IT in many companies. Respondents who point out that the IT director is not a member of the senior management team in their companies identify the small size of the senior management team as the main reason for that (53\%). This coincides with an interesting fact that it is more common that the IT director is not a member of the senior management team in small companies. Other reasons often include that IT is of supportive nature and that IT is adequately represented by another member of the senior executive team (28\% and 23\% for the options, respectively). ${ }^{7}$

\section{CONCLUSION}

Information technologies have a significant role in the corporate governance in companies, both in Serbia and around the globe. They not only work in line with business goals but also support business goals in an effective and purposeful manner. Day by day, their importance is more and more increasing and it could be said that today - they represent an inevitable segment in successful business operations.

Key findings from the conducted research include the following conclusions:

- IT is considered to be essential or very important for the delivery of the overall business strategy and vision by more than 95 percent of participants.

7 Radovanović, D. (2016). Uticaj kontrole i revizije informacionih sistema na uspešnost i efikasnost upravljanja i poslovanja kompanija u Srbiji, Univerzitet Singidunum, 171. 
- IT contributions to business are recognized, while creating value from IT investments is one of the most important dimensions (nine out of ten participants confirmed that).

- 66 percent of the participants mentioned that the IT director is a member of the senior management team, confirming the growing importance of IT in many companies. This position in the senior management team is more likely to occur in companies with 200 or more employees $(85 \%)$ than in those with less than 200 employees (15\%).
Corporate governance in information technology management is an activity related to the use of advanced technologies and a high degree of professional knowledge, as well as general knowledge in organizational management theory. The success of overall business management is directly related to information technology management. Information technologies are one of the key factors of corporate governance.

Figure 4. IT director as a member of the senior management team

\section{LITERATURE}

Cater-Steel, A. (2008). Information Technology Governance and Service Management: Frameworks and Adaptations, IGI Global. 2008.

Haes, S. D., \& Grembergen, W. V. (2009). An Exploratory Study into IT Governance Implementations and its Impact on Business/IT Alignment, Information Systems Management, Vol. 26, 2009, pp.123-137.
ITIL, (2007). An Introductory Overview of ITIL V3. London: The UK Chapter of the it SMF, 2007.

Radovanović, D. (2016). Uticaj kontrole i revizije informacionih sistema na uspešnost i efikasnost upravljanja i poslovanja kompanija u Srbiji, Univerzitet Singidunum.

Weill, P., \& Ross, J. W. (2004). IT governance - How top performers manage IT decision rights for superior results, Harvard Business School Press, 2004. 